\section{IPR Aimoré - Triticale cultivar of early maturity and wide adaptation}

\section{Carlos Roberto Riede ${ }^{1}$, Luiz Alberto Cogrossi Campos ${ }^{1}$, Klever Márcio Antunes Arruda ${ }^{1 *}$, Deoclécio Domingos Garbuglio ${ }^{1}$ and Avahy Carlos da Silva ${ }^{2}$}

\begin{abstract}
IPR Aimore is a new triticale cultivar that combines earliness and high yield. In Value for Cultivation and Use trials carried out in 33 environments, involving the main triticale producing states, IPR Aimoré surpassed $4 \%$ the controls means, with mean yield of $4.955 \mathrm{~kg} \mathrm{ha}^{-1}$.
\end{abstract}

Key words: $x$ Triticosecale Wittmack, earliness, grain yield.

\section{INTRODUCTION}

Characteristics such as high potential of grain and biomass yield, resistance to diseases, such as leaf rust and powdery mildew, adaptation to acid and low fertile soils, and tolerance to drought and cold (Mergoum et al. 2009, Arseniuk 2015), make triticale (x Triticosecale Wittmack) a great alternative for succession and rotation in agricultural production systems, mainly for no-tillage system on straw, since it provides good vegetation cover for the successor culture, even under stress conditions.

Triticale grains can be used for several purposes. In human feeding, its flour has been used to compose mixtures with wheat flour for the manufacture of low fermentation products, such as cookies, pizza dough, meatballs, waffles, and cakes. However, although this cereal presents potential use in human feeding, it is mainly used in Brazil and in the world as animal feeding, in full or partial substitution of other cereals in feed composition (Nascimento Junior et al. 2004). Recently, triticale has also aroused interest for biofuel production, and it has presented competitiveness when compared with other winter cereals (McGoverin et al. 2011).

Triticale production estimates in Brazil, for the year of 2014, was of 95,800 tons, with mean grain yield of about $2,450 \mathrm{~kg} \mathrm{ha}^{-1}$ (CONAB 2015). The national production is mainly concentrated in the states of São Paulo, Paraná and Rio Grande do Sul. In these states, winter crops have been used to diversify agricultural activity, to distribute the cultivation costs throughout the year, and even to increase the yield potential of summer crops.

However, farmers require cultivars that are suitable to the production system, in order to not only allow the installation of summer crops at the most appropriate time, but also to allow the adoption of procedures that reduce risks associated with winter crops. In this context, the availability of cultivars with different cycles gives the farmer an increase in the seeding period, and consequently in the harvest period, reducing risks of losses by frost and rain.
Crop Breeding and Applied Biotechnology 16: 361-364, 2016 Brazilian Society of Plant Breeding. Printed in Brazil http://dx.doi.org/10.1590/1984$70332016 v 16 n 4 c 53$
*Corresponding author: E-mail: klever@iapar.br

Received: 17 March 2015 Accepted: 17 July 2016

${ }^{1} 1$ Instituto Agronômico do Paraná (IAPAR), Rod. Celso Garcia Cid, km 375, CP 10.030, 86.047-902, Londrina, PR, Brazil

${ }^{2}$ IAPAR, Av. Euzébio de Queirós, s/no, Uvaranas, CP 129, 84.001-970, Ponta Grossa, PR, Brazil 


\section{BREEDING METHOD}

The triticale cultivar IPR Aimoré was obtained by the Agronomic Institute of Paraná (IAPAR), in partnership with the International Center for Maize and Wheat Research (CIMMYT) based in Mexico. The material originated from the cross 804/BAT/3/MUSX/LYNX//STIER_12-3/4/VARSA_3-1/5/FAHAD_8-1*2//HARE_263/CIVET, whose genealogy or obtainment process is coded as CTSS98Y00236S-0M-1Y-0M-OY-8B-1Y-0B. This code means that the cross n. 236 originated the material, in chronological order of triticale crosses at CIMMYT, carried out in the year of 1998. The letters refer to Mexican locations where crosses and selections were carried out, i.e., Yaqui Valley (Y), located to the South of the state of Sonora, and Toluca (M) and El Batan (B), located in the state of Mexico. The modified pedigree method was used, in which from the $F_{3}$ generation onwards, individual plants were selected, whose progenies were alternately evaluated in the form of bulk (OM, OY, OB), or in the form of individual plants (1Y, 8B), re-selected, or discarded in successive inbreeding generations until the $F_{8}$ generation. Afterwards, the advanced breeding line was mass selected and included in a collection named $38^{\text {th }}$ International Triticale Yield Nursery (38 ITYN), received by IAPAR in 2006. The accession CTSS98Y00236S-0M-1Y-0M-0Y-8B-1Y-0B was initially evaluated by IAPAR in Ponta Grossa - Paraná, in a collection, in the year of 2007, and in Grain Yield Preliminary Trials, from 2008 to 2009, together with the other accessions previously selected, and which had already been internally coded as TPOLO 0608 . Since the line TPOLO 0608 had stood out in previous reviews, it was promoted to Regional VCU trials (Triticale Meridional Trial), carried out by the network partnership between IAPAR, Fundação Meridional and Embrapa Soybean, in different homogeneous regions of cultivars adaptation (Brasil 2008).

The main agronomic characteristics of TPOLO 0608 line were presented in internal meeting of IAPAR, held in 2013, in order to decide regarding its possible release as a new cultivar. Given the presented yield potential and early maturity, which had already been a demand for cereal producers, it was decided for the release as a new Triticale cultivar, IPR Aimoré, and for the registration at the Ministry of Agriculture, Livestock and Supply (MAPA).

\section{CULTIVAR CHARACTERISTICS}

The characteristics of the cultivar IPR Aimoré were evaluated in 33 Value for Cultivation and Use (VCU) trials in homogeneous regions of adaptation 1 (cold, wet and high altitude), 2 (moderately warm, wet and low altitude), and 3 (hot, moderately dry, and low altitude) in Paraná (PR), São Paulo (SP), Santa Catarina (SC), and Mato Grosso do Sul (MS), from 2010 to 2012. Table 1 shows the Brazilian municipalities where the VCU trials were carried out.

The mean grain yield superiority of cultivar IPR Aimoré was 3, 6 and $3 \%$ in relation to the two best controls, cultivars BRS 203 and IPR 111, in regions 1, 2 and 3, respectively (Table 2). Considering all the environments, the mean overall

Table 1. Locations where the Value for Cultivation and Use Trials of cultivar IPR Aimoré (line TPOLO 0608) were carried out

\begin{tabular}{|c|c|c|c|c|}
\hline State & Locations & Geographic coordinates & Altitude $(\mathrm{m})$ & Homogeneous region \\
\hline \multirow{9}{*}{ PR } & Cambará & $23^{\circ} 00^{\prime} \mathrm{S}, 50^{\circ} 01^{\prime} \mathrm{W}$ & 460 & 3 \\
\hline & Cascavel & $24^{\circ} 57^{\prime} \mathrm{S}, 53^{\circ} 28^{\prime} \mathrm{W}$ & 613 & 2 \\
\hline & Cruzmaltina & $24^{\circ} 00^{\prime} \mathrm{S}, 51^{\circ} 24^{\prime} \mathrm{W}$ & 752 & 3 \\
\hline & Guarapuava & $25^{\circ} 23^{\prime} \mathrm{S}, 51^{\circ} 30^{\prime} \mathrm{W}$ & 1098 & 1 \\
\hline & Irati & $25^{\circ} 28^{\prime} \mathrm{S}, 50^{\circ} 38^{\prime} \mathrm{W}$ & 850 & 1 \\
\hline & Londrina & $23^{\circ} 22^{\prime} \mathrm{S}, 51^{\circ} 10^{\prime} \mathrm{W}$ & 543 & 3 \\
\hline & Pato Branco & $26^{\circ} 08^{\prime} \mathrm{S}, 52^{\circ} 39^{\prime} \mathrm{W}$ & 736 & 2 \\
\hline & Ponta Grossa & $25^{\circ} 05^{\prime} \mathrm{S}, 50^{\circ} 01^{\prime} \mathrm{W}$ & 969 & 1 \\
\hline & Tibagi & $24^{\circ} 31^{\prime} \mathrm{S}, 50^{\circ} 32^{\prime} \mathrm{W}$ & 832 & 2 \\
\hline SP & Itaberá & $23^{\circ} 49^{\prime} \mathrm{S}, 49^{\circ} 03^{\prime} \mathrm{W}$ & 675 & 2 \\
\hline SC & Abelardo Luz & $26^{\circ} 34^{\prime} \mathrm{S}, 52^{\circ} 21^{\prime} \mathrm{W}$ & 850 & 2 \\
\hline
\end{tabular}


IPR Aimoré - Triticale cultivar of early maturity and wide adaptation

Table 2. Mean grain yield ( $\left.\mathrm{kg} \mathrm{ha}^{-1}\right)$ of cultivar IPR Aimoré, evaluated in three regions of VCU trials in the states of PR, SP, SC and MS, in the years of 2010 to 2012

\begin{tabular}{|c|c|c|c|c|c|c|c|}
\hline Region & Year & N. of Trials & IPR Aimoré & IPR 111 & BRS 203 & $\mathrm{CM}^{1}$ & $\mathrm{CM}^{2}$ \\
\hline \multirow{4}{*}{1} & 2010 & 2 & 4.680 & 2.379 & 5.436 & 3.907 & 120 \\
\hline & 2011 & 4 & 5.841 & 6.168 & 5.781 & 5.975 & 98 \\
\hline & 2012 & 3 & 4.323 & 4.607 & 3.938 & 4.273 & 101 \\
\hline & Mean & & 5.077 & 4.806 & 5.090 & 4.948 & 103 \\
\hline \multirow{2}{*}{2} & 2010 & 4 & 6.946 & 5.775 & 6.688 & 6.231 & 111 \\
\hline & 2011 & 3 & 5.363 & 6.105 & 4.677 & 5.391 & 99 \\
\hline \multirow{4}{*}{3} & 2010 & 4 & 4.608 & 3.495 & 3.361 & 3.428 & 134 \\
\hline & 2011 & 5 & 4.094 & 4.255 & 3.621 & 3.938 & 104 \\
\hline & 2012 & 3 & 2.957 & 4.634 & 3.969 & 4.302 & 69 \\
\hline & Mean & & 3.981 & 4.096 & 3.621 & 3.859 & 103 \\
\hline
\end{tabular}

${ }^{1}$ Controls means (IPR 111 and BRS 203)

${ }^{2}$ Performance in relation to the controls means, in percentage

gain was $4 \%$, and the higher yields were obtained in the regions of VCU 1 and 2 . Table 2 presents the mean grain yield per homogeneous region of adaptation and cultivation year.

In the mean of both experiments, IPR Aimoré proved to present very early maturity, since heading occurs about 53 days after emergence, and maturation occurs at 112 days after emergence. When compared with the other seven triticale cultivars registered at MAPA, which were recommended for cultivation in the year of 2014 (Reunião 2014), IPR Aimoré presented higher earliness in all environments evaluated, especially the homogeneous region of adaptation 3, where this cultivar had an mean cycle of only 102 days. For comparison, BRS Harmonia, which has the second shortest cycle among the evaluated cultivars, had 11-days longer cycle in this region (Table 3).

The ears of the cultivar IPR Aimoré are awned, of clear color and fusiform, with long, light red colored soft grains. In relation to other characteristics of interest, the cultivar presented medium height $(99 \mathrm{~cm})$, moderate resistance to lodging and natural threshing. It also presented moderate tolerance to aluminum toxicity, and susceptibility to preharvest sprouting. In relation to physical parameters of the grains, IPR Aimoré presented Hectoliter weight variation between 61 and 81 , with a mean of $75 \mathrm{~kg} \mathrm{hL}^{-1}$. Regarding the weight of 1000 grains, there was variation between 36 and 55 , with mean of 46 grams, which is a very good value for triticale. Table 3 shows the mean data per homogeneous region of adaptation, of some characteristics of interest of cultivar IPR Aimoré, as well as of other triticale cultivars.

In relation to the major diseases that occur in the region, IPR Aimoré is moderate resistant to yellow spot (Drechslera tritici-repentis) and moderately susceptible to leaf rust (Puccinia triticina), brown spot (Bipolaris sorokiniana), and Septoria (Septoria nodorum). Similarly to all other triticale cultivars, IPR Aimoré proved to be susceptible to head blast (Magnaporthe grisea) and scab (Gibberella zeae).

The cultivation of IPR Aimoré is recommended for the regions of VCU 1 (Paraná and Santa Catarina), 2 (Paraná, Santa Catarina and São Paulo) and 3 (Paraná and Mato Grosso do Sul). In function of its earliness, sowing should be carried out from the middle of the time indicated to the region, consequently reducing the risk of loss by frost in the critical stage of the culture, in cold regions, and in order to escape from head blast, in warmer regions.

With the increasing demand for food resources, either for human or animal feeding, and for renewable energy sources, it has been intensified the search for species which are able to diversify the production system and to increase profitability and sustainability of agriculture. Most triticale cultivars available in Brazil, e.g., BRS Harmonia (Nascimento Junior et al. 2015) and IPR 111 (Silva et al. 2006), are of intermediate cycle. Additionally, the number of triticale cultivars developed by breeding programs is still limited, and consequently the number of varieties available to farmers is also limited. In this context, the new triticale cultivar IPR Aimoré may represent an excellent contribution to the Cereal Supply Chain. 
Table 3. Mean of different agronomic characteristics of cultivar IPR Aimoré and of other triticale cultivars, per homogeneous region of adaptation

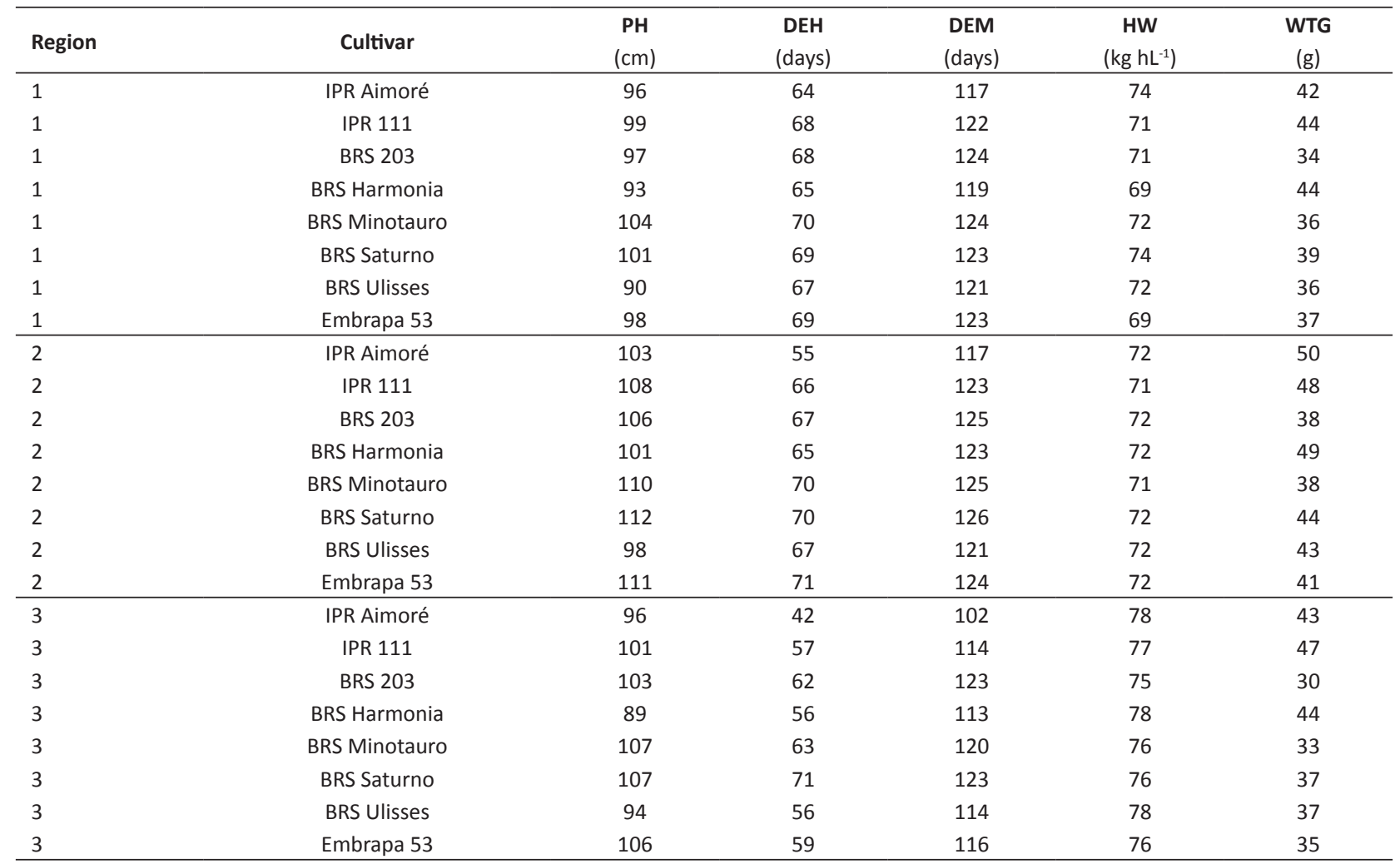

PH: Plant Height; DEH: Days from Emergency to Heading; DEM: Days from Emergency to Maturation; HW: Hectoliter Weight; WTG: Weight of 1000 grains.

\section{BASIC SEEDS PRODUCTION}

The triticale cultivar IPR Aimoré is registered at the National Register of Plant Varieties of the Ministry of Agriculture, Livestock and Supply (RNC/MAPA), under the registration number 31412. IAPAR is responsible for the production and marketing of basic seeds. IPR Aimoré is the first triticale cultivar released by the partnership between IAPAR and Fundação Meridional, which supports the evaluation network of VCU trials and the logistics for the distribution and dissemination of new cultivars.

\section{REFERENCES}

Arseniuk E (2015) Triticale abiotic stresses-An overview. In Eudes F (ed) Triticale. Springer, New York, p. 69-81.

Brasil - Ministério da Agricultura, Pecuária e Abastecimento (2008)

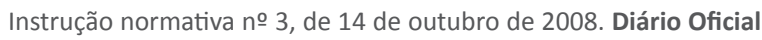
[da] República Federativa do Brasil, 15 outubro 2008. Seção 1, p. 31.

CONAB - Companhia Nacional de Abastecimento (2015) Acompanhamento da safra brasileira de grãos 2014/2015 - quinto levantamento, fevereiro 2015. Available at < http://www.conab.br >. Accessed on February 21, 2015.

McGoverin CM, Snyders F, Muller N, Botes W, Fox G and Manley M (2011) A review of triticale uses and the effect of growth environment on grain quality. Journal of the Science of Food and Agriculture 91: 1155-1165.
Mergoum M, Singh PK, Peña RJ, Lozano-del Río AJ, Cooper KV, Salmon DF and Gómez Macpherson H (2009) Triticale: a "new" crop with old challenges. In Carena MJ (ed) Cereals. Springer, New York, p. 267-287.

Nascimento Junior A, Baier AC, Teixeira MCC and Wiethölter S (2004) Triticale in Brazil. In Mergoum M and MacPherson HG (Org) Triticale improvement and production. $1^{\text {st }}$ edn, FAO, Roma, p. 93-98.

Nascimento Junior A, Bassoi MC, Silva MS, Caierão E and Miranda MZ (2015) BRS Harmonia - triticale cultivar. Crop Breeding and Applied Biotechnology 15: 40-42.

Reunião da Comissão Brasileira de Pesquisa de Trigo e Triticale (2014) Informações técnicas para trigo e triticale - safra 2014. Fundação Meridional, Londrina, 235p.

Silva AC, Riede CR, Campos LAC, Pola JN and Shioga PS (2006) “IPR 111" - Triticale cultivar. Crop Breeding and Applied Biotechnology 6: $250-252$ 